\title{
Parietolith: Uncommon but Preventable Complication of Gall Stone Spillage after Laparoscopic Cholecystectomy
}

\author{
Dr R.K. Chrungoo ${ }^{1}$, Dr Tariq Ahmed Mala ${ }^{2}$, Dr Gurpreet Singh ${ }^{3}$, \\ Dr Sandeep Mohan ${ }^{4}$, Dr Shahid Amin Malla ${ }^{5}$, Dr A. Kumar ${ }^{6}$ \\ 1 (M.S,FICS, FIAGES) Professor Surgery ASCOMS and Hospitals Jammu (J\&K) India \\ 2 Postgraduate department of Surgery ASCOMS and Hospitals Jammu (J\&K) India \\ 3 Assistant professor department of Surgery ASCOMS and Hospitals Jammu (J\&K) India \\ 4 Senior Resident department of Surgery ASCOMS and Hospitals Jammu (J\&K) India \\ 5 M.B.B.S Student S.S. Medical college Rewa (M.P) India \\ 6 Professor Surgery ASCOMS and Hospitals Jammu (J\&K) India
}

\begin{abstract}
We are reporting an uncommon but preventable complication of an ectopic placement of gall stone after spillage following laparoscopic cholecystectomy in a 60yrs old patient who presented with an infraumblical discharging sinus over an old surgical scar. Ultrasonography showed thick walled parietal wall sinus tract at the scar site with minimal fluid collection with presence of a curvilinear hyper intense shadowing in fluid collection. On operation it was found that a large stone was present in the depth of sinus tract. This stone was lodged in a pocket in the preperitoneal space much below the umbilicus and not in any way near the lower extreme of falciform ligament.
\end{abstract}

Keywords: abdominal abscess, transdiaphramatic migration, discharging sinus/fistula

\section{Introduction:-}

Perforation of the gall bladder occurs sometimes during laparoscopic cholecystectomy and is reported in the range of $10 \%-40 \%$ in various series'while spillage of stones have been reported to occur in $5 \%-40 \%$ of case $(1,2)$. Stones spilled at the time of laparoscopic cholecystectomy may remain in the peritoneal cavity adjacent to the liver or spillage may occur during dissection of the gall bladder off the liver bed, tearing with grasping forceps, or during extraction of the gall bladder through one of the port sites(3). The incidence is more common when operating on an acutely inflamed gall bladder (3)' it is also more common in males, the elderly, obese patients, and in the presence of adhesions. In majority of cases these remain asymptomatic but sometimes they may lead to range of complications $(4,5)$.

\section{Case Report:-}

A $60 y$ r old female patient with known diabetes mellitus since 8yrs on oral hypoglycemic drugs and hypothyroidism since 6 months was admitted as a case of infraumblical discharging sinus of three months duration. She was apparently alright three months back when she started having itching in the infraumblical area over the old surgical scar, which was followed by formation of a small pustule which ruptured after few days with passage of foul smelling discharge. She took oral antibiotic for one week and discharge decreased in both quantity as well as quality and it became thin watery non foul smelling and intermittent. Her past surgical history was hysterectomy, 24yrs back for fibroid uterus, and laparoscopic cholecystectomy done $2 \mathrm{yrs}$ back. Post operative period was uneventful after both surgeries. On admission patient denied fever, pain over the sinus region, her temperature was $37.2^{\circ} \mathrm{C}$.

On local examination a small sinus tract was present below the umblicus over the old surgical scar which showed serous thin discharge without any signs of local inflammation. On examination, laboratory testing revealed leukocyte count of $8000 \mathrm{cell} / \mathrm{s} / \mathrm{mm} 3, \mathbf{E S R}=20$, ultrasound abdomen showed thick walled parietal wall sinus tract at the scar site in lower abdomen with minimal fluid collection showing a curvilinear hyper intense shadowing in fluid collection with no entrapment of gut loops.

\section{Operative Findings:-}

Excision of the sinus tract was done which showed a large $1 / 1 \mathrm{~cm}$ stone at the depth of tract. On histopathology sinus showed chronic granulation tissue with intense lymphoplasmacytic infiltration, no evidence of granulomatous or malignant pathology. 


\section{Discussion:-}

Nowadays laparoscopic cholecystectomy is gold standard treatment for symptomatic cholelithiasis (6). The incidence of gallbladder perforation is believed to occur more that of the traditional open method, although. During laparoscopic cholecystectomy, there are three ways by which perforation of gall bladder can occur. First, the gallbladder is used for traction to assist in the dissection of the cystic duct and cystic artery. This leads to excessive traction on gall bladder and graspers that may tear the wall of the gall-bladder. Secondly, the gallbladder may be punctured during dissection from the liver bed. Finally, the gallbladder is extracted from the abdomen through a small incision, at which time it may be put under high pressures. Perforation is easily avoided if extension of the skin incision is per-formed when needed. The amount of inflammation may also contribute to the rate of perforation. The reported abdominal complication rate after spillage of stones is $1.4 \%$. The most common complication of retained stones is abdominal abscess $(7,10)$. Huang and colleagues (11) found that 12 of 20 gallbladders perforated were acutely inflamed. There are case reports of gallstones lost at the time of surgery subsequently causing intra-abdominal abscesses $(7,10)$ empyema (7) abdominal wall abscesses $(12,14)$, cutaneous sinus tract $(15,16)$ and bladder fistulas $(17)$. A study conducted in rats by Gurleyik et al came to the conclusion that chemical composition of the stones has a significant influence on the fate of intraabdominal gall stones, and infection may aggravate local reactions and complication (18). Infective complications are more likely to occur with bilirubinate stones because these stones often contain viable bacteria (19). Migration of stones through the diaphragm has been described in case reports, but mainly secondary to subphrenic abscess. The underlying patho physiologic process involves inflammatory reaction secondary to the presence of retained stones. They may then erode through the diaphragm and cause a bronchopleural fistula with cholelithopthysis, thoracic empyema (20) or pulmonary abscess (21).

\section{Conclusion:-}

Gall bladder perforation during laparoscopic cholescystectomy is a common problem but the serious complications after intra operative spillage of gall stones is very low and every effort should be made to avoid such type of early or late complications which can be a diagnostic challenge and leads to significant morbidity. Older, debilitated patients especially having some co-morbid conditions (i.e. IDDM) have greater chances of complications after spillage of stones. Meticulous surgical technique is the best preventative measure of the low incidence of intra abdominal abscess, immediate laparotomy is not indicated, but attempts should be made to remove all the stones laparoscopically, patient should be informed by the surgeon preoperatively about the possibility of gallstone spillage. They can present months or years after the cholecystectomy with septic complications not necessarily located in the right upper quadrant. We want to highlight our case only because at the time of delivery of gall bladder through epigastric or umbilical port every effort should be made to facilitate easy passage and, one should have continuous watch to see any spillage of gall stones. Retrieval bags can be used safely to minimize the chances of any future complications like abdominal abscess, sinus or fistula.

\section{References:-}

[1] Bhatti CS, Tamijmarane A, Bramhall SR: A tale of three spilled gallstones: one liver mass and two abscesses. Dig Surg 2006, 23:198-200

[2] Yadav RK, Yadav VS, Garg P, et al.: Gallstone expectoration following laparoscopic

[3] cholecystectomy. Indian J Chest Dis Allied Sci 2002, 44:133-135

[4] Hand AH, Self ML, Dunn E: Abdominal wall abscess formation two years after laparoscopic cholecystectomy. JSLS 2006, 10:105107.

[5] Zorluog Lu A, O“ zgu“ c, H, Yilmazlar T, et al. Is it necessary to retrive dropped gallstones during laparoscopic cholecystectomy? Surg. Endosc. 1997;11:64-66

[6] Memon MA, Deeik RK, Mafii TR, et al. The outcome of unretrieved gallstones in the peritoneal cavity during laparoscopic cholecystectomy. Surg. Endosc. 1999; 13:848-857

[7] Tschmelitsch J, Glaser K, Klingler A, et al. Late complication caused by stone spillage during laparoscopic cholecystectomy [letter]. Lancet 1993; 342:369.

[8] Wilton PB, Andy OJ Jr, Peters JJ, et al. Laparoscopic cholecystectomy. Leave no (spilled) stone unturned [see comments]. Surg Endosc 1993; 7:537-538.

[9] Dreznik Z, Soper NJ . Trocar site abscess due to spilled gallstones: An unusual late complication of laparoscopic cholecystectomy. Surg Laparosc Endosc 1993; 3:223-224.

[10] Eldar S, Schein M. Discharge of a gallstone 1 year after laparoscopic Cholecystectomy (petter]. Arch Surg $1994 ; 12$ 9: 1105.

[11] Catarci M, Zaraca F, Scaccia M, et al. Lost intraperitoneal stones after laparoscopic cholecystectomy: Harmless sequela or reason for reopen\&on? Surg Laparosc Endosc 1993; 3:3 18-322.

[12] Huang CS, Tai FC, Shi MY, Chen SF, Wang NY. Complications of laparoscopic cholecystectomy: An analysis of 200 cases. J Formos Med Assoc. 1992;91:785-792.

[13] Sax HC, Adams JT The fate of the spilled gallstone [letter]. Arch Surg 1993; 128:469.

[14] Eldar S, Schein M. Discharge of a gallstone 1 year after laparoscopic Cholecystectomy (petter]. Arch Surg $1994 ; 12$ 9: 1105.

[15] Catarci M, Zaraca F, Scaccia M, et al. Lost intraperitoneal stones after laparoscopic cholecystectomy: Harmless sequela or reason for reopen\&on? Surg Laparosc Endosc 1993; 3:3 18-322.

[16] Cacdac RG, Lakra Yp. Abdominal wall sinus tract secondary to gallstones: A complication of laparoscopic cholecystectomy [review]. J Laparoendosc Surg 1993; 3:509-511. 
[17] Chia JK, Ross M. Gallstones exiting the urinary bladder: A complication of laparoscopic cholecystectomy [letter]. Arch Surg 1995; 130:677.

[18] Donohue JH, Grant CS, Farnell MB, et al. Laparoscopic Cholecystectomy-Operative technique. Mayo Clin Proc 1992; 67:441-448.

[19] Gurleyik E, Gurleyik G, Yucel O, et al. Does chemical composition have an influence on the fate of intraperitoneal gallstone in rat? Surg Laparosc Endosc 1998; 8:113-6.

[20] Johnston S, O'Malley K, McEntee G, Grace P, Smyth E, Bouchier-Hayes DB. The need to retrieve the dropped stone during laparoscopic cholecystectomy. Am J Surg. 1994; 167:608

[21] Barnard SP, Pallister I, Hendrick DJ. Cholelithoptysis and empyema formation after laparoscopic cholecystectomy Ann Thor Surg 1997;60:1100-1102.

[22] Zehetner J, Shamiyeh A, Wayand W: Lost gallstones in laparoscopic cholecystectomy: all possible complications. Am J Surg 2007, 193:73-78. 